\title{
FACTORS THAT AFFECT AWARENESS ABOUT THE SPREAD OF HIV/AIDS IN RURAL LESOTHO
}

\author{
Amelia Ranotsi \\ Ph D RN, RM, OTT \\ Lecturer of Nursing, Department of Nursing, National University of Lesotho
}

\section{Zeleke Worku}

Ph D

Senior Lecturer of Biostatistics, School of Health Systems and Public Health, University of Pretoria

Corresponding author: worku@med.up.ac.za

Keywords: awareness; HIVIAIDS; association; odds ratio; home based care; Lesotho

\begin{abstract}
A stratified random sample of 401 participants was taken from three sites of study (Maluti, Seboche and Paray) in rural Lesotho in an attempt to study the relationship between awareness about HIVIAIDS and 55 socio-economic and demographic variables. Pearson's chi-square tests of association and logistic regression analysis were used to identify factors that strongly affected awareness about HIV/AIDS. Results showed that awareness about HIVIAIDS was strongly affected by willingness to change sexual behaviour, regular use of condoms, sexually transmitted diseases, number of sexual partners and knowledge of transmission of the HIV/AIDS virus. Recommendations were made to promote health education in rural Lesotho on safe sex and the use of home-based care for people living with the virus.
\end{abstract}

\section{OPSOMMING}

In 'n poging om die verband tussen die bewustheid van HIVIVIGS en 55 sosio-ekonomiese en demografiese veranderlikes te bestudeer, is 'n gestratifiseerde ewekansige steekproef van 401 deelnemers in drie studie-areas in die platteland van Lesotho (Maluti, Seboche en Paray) gedoen. Pearson se chi-kwadranttoets vir assosiasie en regressie-analise is gebruik om faktore wat 'n sterk invloed op die bewustheid van HIVIVIGS het te identifiseer. Resultate toon dat bewustheid van HIVIVIGS sterk beïnvloed word deur die bereidheid om seksuele gedrag te verander, gereelde gebruik van kondome, seksuele oordraagbare siektes, getal seksuele kontakte en kennis van die oordraagbaarheid van die HIVIVIGS virus. Aanbevelings is gemaak om gesondheidsopvoeding in landelike Lesotho met betrekking tot veilige seksuele gedrag en die tuisversorging van vigslyers te bevorder. 


\section{INTRODUCTION}

Lesotho is one of nine Sub-Saharan countries where the prevalence of HIVIAIDS among adults is $28.9 \%$. Awareness about the disease in rural areas of Lesotho is low in comparison with South Africa. Many young men from rural Lesotho work in South African mines, an industry that is severely affected by the spread of HIVIAIDS (UNAIDS, 2004:1-4). Half of Lesotho's 2.2 million people live beneath the poverty line, more than 65 per cent live on less than two US dollars a day. Many work as labourers in South African mines, and come back home for holidays (Export Credit Agencies Watch, 2005:1-4). According to the Population Reference Bureau (2004:1-2), Lesotho is one of the poorest countries of the world that are constantly threatened with extreme poverty and health disparities.

Retrenchments in South African mines and the subsequent massive influx of Basotho mineworkers from South African mines back to rural Lesotho adversely affect rural communities in terms of socio-economic, demographic and health-related factors. Some of the retrenched mineworkers are HIV-positive, and return home with the disease, a place where awareness about the virus is much lower than in South Africa. According to Family Health International (2005:3-10), ORC MACRO (2004:1-11), McIntyre (2002), the Lesotho Planned Parenthood Association (2002:1-12), the Lesotho Ministry of Health and Social Welfare (2003:1-5), the USAID (2001:1-15) and the UNDP (2005:1-4), the threat from mineworkers coming back home from South African mines following retrenchment is quite significant, and there is a need to educate the rural community in Lesotho about protective measures such as the use of condoms. However, such efforts are mainly restricted to urban areas only, and are not integrated adequately by the Health Ministry.

Maluti, Seboche and Paray are three predominantly rural towns of Lesotho consisting of roughly 10000 households. The level of education and average monthly income of people living in these three rural towns are low. The majority of people at the three towns are dependent on farming. The proportion of female heads of households is above $50 \%$. Less than $25 \%$ of inhabitants are formally employed. It is usual for male heads of households to look for employment opportunities in larger towns of Lesotho or in South African mines.

\section{BACKGROUND OF STUDY}

This is a KABP (knowledge, attitude, behaviour and practice) study carried out in three rural towns of Lesotho: Maluti, Seboche and Paray to identify factors that strongly affect awareness about HIVIAIDS. The three sites of study are Health Service Areas that are under the Christian Health Association of Lesotho (CHAL). CHAL has contributed significantly to the provision of health care in the country in areas related to HIVIAIDS. The study was sponsored by the Brystol Meyers Foundation in response to the soaring number of people infected with HIVIAIDS seeking assistance from CHAL.

The prevalence of HIV in Lesotho in the year 2004 among adults between 15 to 49 years of age was $28.9 \%$. At the end of 2003, there were a total of 29000 AIDSrelated deaths in Lesotho. Life expectancy at birth could drop to below 40 years due to HIV over the next two decades, if HIV continues to spread at the present rate. About $25 \%$ of the adult population aged between 15 and 49 years is currently infected with AIDS. Most of those infected do not even know that they are infected (UNAIDS, 2004:1-7). The migration of rural Basotho people to South African mines is motivated by chronic poverty and unemployment in Lesotho (Oucho, 2002:111).

The AIDS problem in Lesotho is exacerbated due to the following factors: high prevalence of sexually transmitted infectious diseases (STI), multiple sexual relationships, low use of condoms, poverty, low health status of much of the population, malnutrition, low status of women, settlement patterns, worker migration and harmful traditional and cultural practices. The exchange of sex for money or gifts is a coping strategy for dealing with poverty (UNAIDS, 2001:12-47).

Most Basotho people have more than one sexual partner, and are quite vulnerable to the growing threat from HIVIAIDS and sexually transmitted diseases. An HIVI AIDS study conducted in 2002 by Family Health International in Maseru, Leribe and Mafeteng showed that knowledge about AIDS is low among mineworkers and taxi drivers. The study also showed that multiple partnerships are common, and that condom use is low among all age groups (Family Health International, 2002:6-14). 


\section{PROBLEM STATEMENT}

Rural communities in Lesotho need to be educated on how to protect themselves from HIVIAIDS and sexually transmitted diseases. There is a dire need for rural community-based programmes that are suitable for increasing awareness about HIVIAIDS and STI, and for promoting responsible sexual practice and behaviour such as the use of condoms, faithfulness and abstinence from sex prior to marriage. Strategies and methods that have been relied upon so far have not produced adequate results due to flaws in approach, absence of monitoring and evaluation, as well as lack of integration and coordination among competing programmes aimed at curbing the spread of AIDS.

\section{RESEARCH QUESTIONS}

This study aims to answer the following three research questions:

- How big a problem is lack of awareness about ways in which AIDS spreads among the heterosexual population at Maluti, Seboche and Paray? What proportion of the population at the sites of study is adequately aware about the threat of HIVIAIDS?

- What are the major factors that are responsible for lack of awareness about the spread of AIDS at Maluti, Seboche and Paray?

- What practical measures should be taken by the National Health Ministry of Lesotho in order to increase the level of awareness about the spread of HIVIAIDS?

\section{REVIEW OF THE LITERATURE}

According to data from the UNAIDS (2004:1-7), a total of 360000 people out of Lesotho's population of 2.2 million were living with HIVIAIDS in 2003. The HIV prevalence rate in 2004 was $28.9 \%$. It is estimated that 330 000 out of 1 million people (30\%) in the adult age group, 15 to 49 years, are afflicted by the pandemic. The population group, 24 to 40 years, which contributes the most to the country's social, political and economic development, is the most affected by the pandemic. In the year 2003, there were 29000 AIDS-related deaths, and there were 170000 women 15 to 49 years of age living with HIV. Some of the contributing factors are high rate of unemployment $(45 \%)$ in 2003 , poverty and malnutri- tion (World Food Programme, 2005:1-3).

According to the UNICEF (2004:1-6), the estimated number of AIDS orphans in Lesotho in 2003 was 93 000. The Lesotho government fears that a generation of orphans growing up without parents and proper guidance would lead to a major social upheaval that would threaten the stability of the entire country (Mumia, 2005:1-2). Awareness about the spread of HIVIAIDS and STI is very low in rural Lesotho in comparison with South Africa. Most Basotho men have more than one sexual partner. The rural population in Lesotho is particularly vulnerable to the influx of Basotho mineworkers who commute between dangerously affected South African mines and rural Lesotho. Nearly one in three Basotho adults aged 15-49 is now infected with HIV. Life expectancy at birth is 51 years, but it is declining rapidly as a result of HIVIAIDS; some estimates predict that life expectancy at birth could drop to 37 years in the next 15 years (UNAIDS, 2004:1-7) unless drastic measures are taken.

Malnutrition continues to be a problem in Lesotho especially among children. Most of the malnourished children in Lesotho live with their grandparents or relatives after the death of their parents. The spread of HIVIAIDS has the potential to increase the number of malnourished children. It must be noted that the majority of malnourished children are found to be HIV positive. In 2003 , about 430000 people (23\% of the population of Lesotho) were affected by shortage of food according to World Vision International (2003:1-4). According to the World Food Programme (2005:1-3), 31\% of the adult population in Lesotho is living with HIVIAIDS, which is taking its toll on the short and long-term food security of poor communities. With the disease wiping out large numbers of productive farmers and parents, families are left struggling to cope. Half of the population in Lesotho lives below the poverty line.

Lesotho has suffered great human loss due to the AIDS pandemic. Statistics from the Ministry of Health and Social Welfare of Lesotho shows that AIDS infections are highly prevalent in the age group 15 to 39 years. The study by Family Health International (2005:1-14) on sexual behaviours of adolescents in Lesotho as well as results from a study conducted by the Lesotho Planned Parenthood Association (2002:1-15) show that adolescents become sexually active early in their lives 
without any prior information on sex and sexuality, and that HIVIAIDS and sexually transmitted infections spread at an alarming rate among the youth in Lesotho.

In Lesotho, harmful traditional practices such as cutting hair as a sign of mourning for lost members of family, scarification by traditional healers using the same blade, and inheriting spouses of dead husbands spread HIVIAIDS (Monaheng, 2003:1-8). The intensive campaign carried out by the Lesotho Health Ministry to combat the spread of HIVIAIDS has so far produced disappointing results. This failure is attributed mainly to lack of relevance and absence of concrete action. Education must be given on issues such as cultural traditions, social inequalities between sexual partners and the practice of safe sex. AIDS is associated with stigma, and AIDS sufferers are reluctant to disclose their status unless they are provided with care and counselling services. Home-based care and participation in community-based support and counselling programmes have helped people living with AIDS avoid isolation and a sense of despair (Russell, 2001:12).

\section{AIM OF THE STUDY}

This is a KABP (knowledge, attitude, behavior and practice) study whose aim is to find out how much people living in Maluti, Seboche and Paray (three regions in rural Lesotho where this study was carried out) know about the threat of HIVIAIDS and sexually transmitted diseases.

\section{OBJECTIVES}

- To assess the level of awareness about the threat of HIVIAIDS among the rural population of Lesotho living in Maluti, Paray and Seboche.

- To identify factors strongly influencing the level of awareness about HIVIAIDS and their willingness to practice safe and responsible sex and protect themselves from HIVIAIDS and STDs.

- To find out whether or not the difference in knowledge acquisition about HIVIAIDS is explained by age, gender, level of education and marital status.

\section{RESEARCH DESIGN}

\section{Study design, sample size of study and data collection}

This is a population-based descriptive cross-sectional study involving people living in three rural towns in Lesotho. A stratified random sample of 401 heads of households was selected from the three sites of study (Maluti, Seboche and Paray) using techniques of proportional allocation with regards to size (PPS). The three sites of study were treated as three strata. In each of the three towns, eligible households were identified using techniques of systematic random sampling. The sample size of study was determined as 470 heads of households using the statistical package nQuery Advisor version 4.0 (Statistical Solutions Ltd, 2000: A2) by fixing the level of significance at $5 \%$, the proportion of people inadequately aware of HIVIAIDS varying from $10 \%$ to $15 \%$, and the power of study at $92 \%$. Data were actually gathered from only 401 of the 470 households selected for the study, thereby providing a response rate of $85 \%$.

The number of households sampled from Maluti, Seboche and Paray was 164, 127 and 110 respectively. Data collection was carried out by data collectors who were trained specifically for the study by use of a questionnaire consisting of 55 questions. To ensure reliability, the questionnaire of study was pre-tested at Maluti town before it was used. To ensure validity, each of the 401 participants in the study was interviewed face-toface in Sesotho using door-to-door visits in an attempt to avoid bias. The questions asked were socio-economic, demographic, health-related and sanitary variables. At each household, the head of the household was interviewed. Variables consisting of ordinal scales were tested for internal consistency using the CronbachAlpha test (Dawson \& Trapp, 2001:312).

\section{VARIABLES OF STUDY}

Information was collected from the 401 participants in the study by use of a questionnaire consisting of one outcome variable and 55 questions related to the outcome variable of the study. The 55 variables of study were a combination of socio-economic and demographic questions related to the level of awareness of the participant. Examples of the variables of study are overall awareness about HIVIAIDS, residential area, gender, marital status, duration of marriage, age category, number of children, level of education, religion, employment status, level of prior knowledge about HIV/ AIDS, source of prior knowledge about HIVIAIDS, 
knowledge on how HIVIAIDS spreads, knowledge of the fact that there is no cure for AIDS, knowledge of causes of AIDS, knowledge of potential causes of accidental infection, knowledge of mother to child transmission of AIDS, practice of faithful sexual partnership, regular condom use during sexual intercourse, abstinence from sex, attitude towards HIVpositive people, willingness to help HIV-positive people, number of sexual partners, knowledge of friends or family with AIDS, willingness to change sexual behaviour, number of marriage partners over the past five years, episode of sexually transmitted infectious diseases over the past 12 months, knowledge of partner's sexual relationships, level of trust in sexual partner, condom use by sexual partner, scarification, use of blades, use of gloves, and others.

The outcome variable of study is overall awareness about AIDS. Awareness about AIDS is defined as the ability of the particpant to distinguish between myth and reality about how the AIDS virus can be transmitted from an infected person to a healthy individual. A participant is said to be inadequately aware about AIDS if the individual does not know that AIDS can be transmitted by having unprotected sex with an infected person, if the participant believes that there is a cure for AIDS, or if the participant believes that he or she is not vulnerable to AIDS (Trisdale, 2003:1).

\section{ETHICAL CONSIDERATIONS}

Ethics approval was obtained for the Research from Maluti Adventist Hospital and School of Nursing. All participants in the study participated in the study voluntarily, and were fully informed about the purpose and expected output of study. Data were gathered from participants at each household anonymously.

\section{DATA ANALYSIS AND RESULTS}

The 401 participants who took part in the study were mostly rural, and had low to medium levels of income (3 000 Rand per month or less) by Lesotho standards. The main source of livelihood of participants was farming. The average age of the 401 participants in the study was 38.75 years. Fourty percent of the participants had low level of education (elementary level or less). Fiftyfive percent of all participants were married. Eighty-six percent of all participants were not employed. Fourty- nine percent of all participants were Roman Catholic. Sixty percent of heads of households were women.

Frequencies and percentages were obtained for the 55 variables of study. Cross-tabulations and Pearson's chisquare tests of association were also obtained. Overall awareness about HIVIAIDS was strongly influenced by 11 of the 55 variables. Table 2 shows proportions for two groups of people in the study. Group 1 consists of 189 of the 401 people in the study $(47.13 \%)$ whose awareness about AIDS is inadequate. Group 2 consists of 212 of the 401 people in the study $(52.87 \%)$ whose awareness about AIDS is adequate.

The percentages shown in Table 1 as well as two-sample tests on proportions (Dawson \& Trapp, 2001:95-144) showed that there is a significant difference between Group 1 (the 189 people in the study who have inadequate overall awareness about HIVIAIDS) and Group 2 (the 212 people in the study who do have adequate overall awareness about HIVIAIDS) with respect to key behavioural factors that strongly affect the risk of contracting the AIDS disease.

Table 1 shows that most of the 189 people who have inadequate overall awareness about HIVIAIDS are poorly educated, younger than 25 years of age, do not use condoms regularly, have short durations of marriage, have two or more sexual partners, are reluctant to change their sexual behaviour, and have the wrong perceptions on the availability of a cure for HIVIAIDS and the capacity of traditional healers. The table also shows that $32 \%$ of the 189 people who have inadequate overall awareness about HIVIAIDS have experienced at least one episode of a sexually transmitted disease.

Univariate and multivariate analysis were used in two steps in order to select the top five influential predictor variables associated with awareness. Preliminary screening of variables was done on the basis of relevance to the research questions of the study and Pearson's chi-square tests of association (Dawson \& Trapp, 2001:95-144). This procedure led to the selection of 11 out of 55 variables of study. Subsequent screening of variables was done using hierarchical stepwise backward elimination and successive likelihood ratio tests (Kleinbaum \& Klein, 2002:162-226) based on a series of logistic regression analysis procedures. This procedure led to the selection of five of 
Table 1: Group proportions with respect to awareness about HIV/AIDS

\begin{tabular}{|c|c|c|}
\hline Variable & $\begin{array}{l}\text { Inadequate overall } \\
\text { awareness }(n=189)\end{array}$ & $\begin{array}{l}\text { Adequate overall awareness } \\
(\mathrm{n}=212)\end{array}$ \\
\hline Level of education & $\begin{array}{l}\text { Low: } 54 \% \\
\text { High: } 46 \%\end{array}$ & $\begin{array}{l}\text { Low: } 26 \% \\
\text { High: } 74 \%\end{array}$ \\
\hline Age category & $\begin{array}{l}\leq 25 \text { years: } 48 \% \\
>25 \text { years: } 52 \%\end{array}$ & $\begin{array}{l}\leq 25 \text { years: } 66 \% \\
>25 \text { years: } 34 \%\end{array}$ \\
\hline Regular use of condoms & $\begin{array}{l}\text { No: } 77 \% \\
\text { Yes: } 23 \%\end{array}$ & $\begin{array}{l}\text { No: } 29 \% \\
\text { Yes: } 71 \%\end{array}$ \\
\hline Duration of marriage & $\begin{array}{l}\leq 10 \text { years: } 63 \% \\
>10 \text { years: } 37 \%\end{array}$ & $\begin{array}{l}\leq 10 \text { years: } 56 \% \\
>10 \text { years: } 44 \%\end{array}$ \\
\hline $\begin{array}{l}\text { Knowledge of how HIVIAIDS } \\
\text { spreads }\end{array}$ & $\begin{array}{l}\text { Poor: } 81 \% \\
\text { Otherwise: } 19 \%\end{array}$ & $\begin{array}{l}\text { Poor: } 23 \% \\
\text { Otherwise: } 77 \%\end{array}$ \\
\hline Episode of STD last year & $\begin{array}{l}\text { Yes: } 32 \% \\
\text { No: } 68 \%\end{array}$ & $\begin{array}{l}\text { Yes: } 19 \% \\
\text { No: } 81 \%\end{array}$ \\
\hline Gender: & $\begin{array}{l}\text { Male: } 39 \% \\
\text { Female: } 61 \%\end{array}$ & $\begin{array}{l}\text { Male: } 41 \% \\
\text { Female: } 59 \%\end{array}$ \\
\hline $\begin{array}{l}\text { Willingness to change sexual } \\
\text { behaviour }\end{array}$ & $\begin{array}{l}\text { No: } 78 \% \\
\text { Yes: } 22 \%\end{array}$ & $\begin{array}{l}\text { No: } 57 \% \\
\text { Yes: } 43 \%\end{array}$ \\
\hline Number of sexual partners & $\begin{array}{l}\geq 2 \text { partners: } 41 \% \\
\text { Only } 1 \text { partner: } 59 \%\end{array}$ & $\begin{array}{l}\geq 2 \text { partners: } 34 \% \\
\text { Only } 1 \text { partner: } 66 \%\end{array}$ \\
\hline $\begin{array}{l}\text { Perception on cure for } \\
\text { HIVIAIDS }\end{array}$ & $\begin{array}{l}\text { Wrong: } 49 \% \\
\text { Correct: } 51 \%\end{array}$ & $\begin{array}{l}\text { Wrong: } 38 \% \\
\text { Correct: } 62 \%\end{array}$ \\
\hline $\begin{array}{l}\text { Perception on traditional } \\
\text { healers }\end{array}$ & $\begin{array}{l}\text { Wrong: } 76 \% \\
\text { Correct: } 24 \%\end{array}$ & $\begin{array}{l}\text { Wrong: } 39 \% \\
\text { Correct: } 61 \%\end{array}$ \\
\hline
\end{tabular}

the 55 variables of study. Odds ratios from logistic regression analysis were used as a measure of effect (Hosmer \& Lemeshow, 2000:127). Odds ratios adjusted for three potential confounding and/or effect-modifying variables (age category, level of education and gender) that are known to affect awareness were obtained.

Table 2 gives unadjusted and adjusted odds ratios estimated for five important predictor variables that are strongly associated with overall awareness about HIVI AIDS.

Table 2 shows the summary of results from logistic regression analysis. The table ranks the five influential predictor variables in order of their importance. Influential predictor variables are characterised by estimated odds ratios that differ from one significantly, $95 \%$ con- fidence intervals of odds ratios that do not contain one, and $p$-values that are smaller than 0.05 . Accordingly, awareness about HIVIAIDS is strongly affected by willingness to change sexual behaviour, regular use of condom during sexual intercourse, episode of sexually transmitted diseases, number of two or more sexual partners and knowledge of transmission of the HIVIAIDS virus, in a decreasing order of strength. It can be seen from Table 2 that unadjusted and adjusted odds ratios are fairly similar in magnitude for each of the three variables of adjustment. This shows that none of the three variables used for adjustment is a confounding or effect-modifying variable.

\section{Interpretation of odds ratios}

The odds ratio of the variable "willingness to change 
Table 2: Summary of results from logistic regression

\begin{tabular}{|c|c|c|c|c|c|}
\hline Variable & $\begin{array}{l}\text { Unadjusted } \\
\text { odds ratios }\end{array}$ & $\begin{array}{l}\text { Adjusted } \\
\text { odds } \\
\text { ratios }\end{array}$ & P-value & 95\% C. I. & Rank \\
\hline Sexual behaviour & 4.5209 & $4.4509^{*}$ & 0.000 & {$[2.01,5.97]$} & 1 \\
\hline Regular use of condoms & 2.9806 & $3.0102^{*}$ & 0.000 & {$[1.84,5.46]$} & 2 \\
\hline Episode of STD & 2.7789 & $2.8725^{\star}$ & 0.000 & {$[1.64,4.89]$} & 3 \\
\hline Sexual partners & 2.5555 & $2.6403^{*}$ & 0.000 & {$[1.49,4.39]$} & 4 \\
\hline Knowledge of transmission & 2.3214 & $2.4276^{*}$ & 0.001 & {$[1.47,4.06]$} & 5 \\
\hline
\end{tabular}

* Adjustment was done for gender, age category and level of education

sexual behaviour" is 4.45 . This shows that participants who are reluctant to change their sexual behaviour are 4.45 times more likely to be inadequately aware of how HIVIAIDS spreads in comparison with participants who are willing to change their sexual behaviour.

The odds ratio of the variable "regular use of condom during sexual intercourse" is 3.01 . This shows that participants who do not use condoms during sexual intercourse regularly are 3.01 times more likely to be inadequately aware of how HIVIAIDS spreads in comparison with participants who use condoms regularly during sexual intercourse.

The odds ratio of the variable "episode of STD" is 2.87. This shows that participants who have had at least one episode of STD are 2.87 times more likely to be inadequately aware of how HIVIAIDS spreads in comparison with participants who did not experience an STD.

The odds ratio of the variable "sexual partners" is 2.64. This shows that participants who have two or more sexual partners are 2.64 times more likely to be inadequately aware of how HIVIAIDS spreads in comparison with participants who have only one sexual partner.

The odds ratio of the variable "knowledge of transmission" is 2.43. This shows that participants who do not know how HIVIAIDS is transmitted are 2.43 times more likely to be inadequately aware of how HIVIAIDS spreads in comparison with participants who know how the virus is transmitted.

The adequacy of the estimated logistic regression model was assessed using standard diagnostic measures such as the likelihood ratio test $(p=0.0000)$, the percentage of overall correct classification $(91.77 \%)$, the Hosmer-Lemeshow goodness-of-fit test $(p=0.1204)$ and a normal probability plot of residuals that resembled an S-shape. All diagnostic measures showed that the fitted logistic regression model was highly reliable.

\section{DISCUSSION AND RECOMMENDATIONS}

The study has shown that overall awareness about HIV/ AIDS is strongly affected by the following five factors:

- Willingness to change sexual behaviour

- Regular use of condoms

- Episode of sexually transmitted diseases

- Number of sexual partners

- Knowledge of transmission of the HIVIAIDS virus

Results of this study have shown that awareness about AIDS is strongly influenced by five factors out of which four are behavioural and one is related to knowledge. Individuals that are adequately aware of how AIDS spreads are characterised by willingness to change their sexual behaviour and use condoms. Several organisations in Southern Africa are promoting these same two messages using the mass media and entertainment as a tool. One good example is Love Life (2005:1-3), a South African non-governmental organisation that is very highly active in educating and empowering the youth on how to practice safe sex and to abstain from sex prior to marriage. Faith-based institutions such as the church also play an important role in bringing about change in behaviour among the youth as a tool to curb the spread of AIDS. The youth 
must also be educated about ways in which the HIvirus is transmitted.

Over the past several years, awareness about HIVIAIDS has increased in Lesotho as a direct result of campaigns conducted by the Health Ministry, the World Health Organization, UNAIDS, the UNICEF, non-governmental agencies and faith-based institutions. Although the Lesotho Government has accepted more responsibility in educating the masses and combating the epidemic, the prevalence of HIV is still unacceptably high. This indicates that much more should be done by the Government of Lesotho in educating people of all ages on how the disease spreads. Incentives as well as an integrated community based approach must be followed to achieve a sizeable reduction in infection rates of STDs and HIVIAIDS.

The majority of people with HIVIAIDS are cared for at home. As home-based care is provided mainly by families that are adversely affected by the disease, the shift of responsibility from hospital-based care to homebased care, and the subsequent need for AIDS drugs has resulted in a major challenge to the communities with regards to providing AIDS patients with the necessary health care and the emotional support they need. Communities must be empowered if they have to meet the social and economic needs of people living with AIDS.

Willingness to change sexual behaviour and abstinence from pre-marital sex have proved to be reliable methods of curbing the spread of AIDS in countries such as Uganda, and an aggressive effort must be applied to do the same in Lesotho. This task requires the total commitment of the Health and Education Ministries of Lesotho as well as the various non-governmental agencies currently working in Lesotho. The high prevalence of HIVIAIDS in Lesotho shows that people, and especially the youth, must be motivated and educated to consider changing their sexual behaviour and abstinence from pre-marital sex. People seem to be overconfident in their ability to avoid falling victim to the disease.

Studies by Goliber (2000) and Takai, Wongkhomthong, Akabayashi, Kai, Ohi and Nka (1998:482-484) have shown that communities and governments benefit socially and economically by providing people living with AIDS with specialised care. One effective method of assisting people living with AIDS is to reduce the level of stigmatisation exerted on victims of AIDS by educating the community. A report by the World Bank (2004:1-3) urges the Lesotho government to improve efforts that are currently underway to combat the spread of HIVIAIDS by increasing awareness about the disease and by soliciting all available support from nongovernmental organisations and faith-based institutions. Intervention strategies that have been used successfully in countries such as Uganda must be implemented with vigour in order to increase awareness about AIDS and curb its spread.

Based on findings of this study, willingness to change sexual behaviour and the regular use of condoms during sexual intercourse is crucially important factors that could help curb the spread of HIVIAIDS in Lesotho. To specifically assist the rural population of Lesotho in this regard, health education should be given to the rural communities using an integrated and well-coordinated community-based approach. Rural communities should be educated and empowered to protect themselves from HIVIAIDS and look after members of the community who live with the virus using home-based care.

\section{BIBLIOGRAPHY}

DAWSON, B \& TRAPP, RG 2001: Basic Clinical Biostatistics; $3^{\text {rd }}$ edition. New York: Mc-Graw Hill.

EXPORT CREDIT AGENCIES WATCH 2005: Report on Basotho migrant mineworkers working in South African mines. International NGO Campaign on Export Credit Agencies Website. http:// www.eca-watch.org (Accessed: 15 April 2006).

FAMILY HEALTH INTERNATIONAL 2002: HIVIAIDS behavioral surveillance survey. Arlington: Family Health International.

FAMILY HEALTH INTERNATIONAL 2005: Meeting the needs of young clients: A guide to providing reproductive health services to adolescents. Family Health International Website. http:// www.fhi.org/sp/RH/Pubs/servdelivery/adolguide/chapter2.htm (Accessed: 15 April 2006).

GOLIBER, T 2000: Exploring the implications of the HIVIAIDS epidemic for educational planning in selected African countries: The demographic question. An ActAfrica Paper prepared for the Futures Group International Website. http://www.policyproject.com/ pubs/countryreports (Accessed: 15 April 2006).

HOSMER, DW \& LEMESHOW, S 2000: Applied logistic regression; $2^{\text {nd }}$ edition. New York: John Wiley.

INTERNATIONAL CENTER FOR RESEARCH ONWOMEN 2004: How 
to improve access to prevention methods that women can control. An American Research Institution Website Dedicated for Issues of Women. http://www.icrw.org/html/issues/hivaids.htm (Accessed: 15 April 2006).

KLEINBAUM, D \& MITCHELL, K 2002: Logistic regression analysis: A self-learning text. New York: Springer.

LESOTHO MINISTRY OF HEALTH AND SOCIAL WELFARE 2003: National adolescent health policy. Maseru: Lesotho Ministry of Health and Social Welfare.

LESOTHO PLANNED PARENTHOOD ASSOCIATION 2002: Management of unsafe sex among youth project. Maseru: Lesotho Ministry of Health and Social Welfare.

LOVE LIFE 2005: HIVIAIDS, pregnancy, STIs and betrayal. A South African Non-Governmental Organization Website Dedicated for AIDS Education. http://www.lovelife.org.za/kids/index.html (Accessed: 15 April 2006).

MCINTYRE, P 2002: Adolescent friendly services: An agenda for change. Geneva: World Health Organization.

MONAHENG, M 2003: Annual report by the Lesotho AIDS Programme Co-ordinating Agency (LAPCA). Maseru, Lesotho: LAPCA.

MUMIA, P 2005: Increase in AIDS orphans leads to major social upheaval. Geneva: Lutheran World Information

ORC MACRO 2004: Lesotho demographic health survey: Preliminary report, 2004. Maseru: ORC Macro.

OUCHO, JO 2002: The relationship between migration and poverty in Southern Africa. A Research and Publications Website Belonging to Queens University in Canada. http:// www.queensu.ca/Samp/Conferences/Agendas/Agenda7b.pdf (Accessed: 15 April 2006).

POPULATION REFERENCE BUREAU 2004: The World Population Data Sheet 2004. A Population Reference Bureau Website. http:/ /www.prb.org (Accessed: 15 April 2006).

RUSSELL, M 2001: Side case studies on mobilization family and community care for and by people with HIV. New York: UNAIDS. STATISTICAL SOLUTIONS LTD 2000: nQuery Advisor 4.0. Cork, Ireland: Statistical Solutions.

TAKAI, A; WONGKHOMTHONG, SA; AKABAYASHI, A; KAI, I; OHI, G \& NAKA, K 1998: Correlation between history of contact with people living with HIVIAIDS and tolerant attitudes towards HIVI AIDS and PWAS in rural Thailand. International Journal of STD and AIDS, 9(8):482-484.

TRISDALE, SK 2003: HIV: The basics, myths and misperceptions. An American AIDS Charity based in Charlottesville Website. http:/ /www.thewellproject.org (Accessed: 15 April 2006).

UNAIDS 2001: Report on the Global HIVIAIDS Epidemic. Geneva: UNAIDS

UNAIDS 2004: Report on the global AIDS epidemic. A UNAIDS Website. http://www.unaids.org/EN/other/functionalities/
Search.asp (Accessed: 15 April 2006).

UNDP 2005: Lesotho strategic results framework. A UNDP Website. http://www.undp.org.Is/Lesotho_Information/index.htm (Accessed: 15 April 2006).

UNICEF 2004: A crisis in Lesotho: Children without families. A UNICEF Website. http://www.unicef.org/infobycountry/ lesotho_20016.html (Accessed: 15 April 2006).

USAID 2001: HIVIAIDS in Southern Africa: Background, Projections, Impacts and Interventions. A USAID Website. http:// sara.aed.org/sara_pubs_list_usaid_3.htm (Accessed: 15 April 2006)

WORLD BANK 2004: The World Bank Funds The Fight Against HIVIAIDS In The Kingdom Of Lesotho. A World Bank News Release Website. http://web.worldbank.org/lesotho (Accessed: 15 April 2006).

WORLD FOOD PROGRAM 2005: World Hunger - Lesotho. A World Food Program Website. http://www.wfp.org/country_brief/lesotho (Accessed: 15 April 2006).

WORLD VISION INTERNATIONAL 2003: Food Crisis - Lesotho. A World Vision International Website. http://www.wvi.org/wvi/ africa_food_crisis/lesotho_food_crisis.htm (Accessed: 15 April 2006). 